\title{
Building the Character of the National With Culture of Maintaining the Cleanliness of the School Bathroom
}

\author{
$1^{\text {st }}$ Nani Irma Susanti, $2^{\text {nd }}$ Etty Indriani, $3^{\text {rd }}$ Indriyana Widyastuti \\ Naniirma67@gmail.com ${ }^{1}$ - ettyaub@yahoo.co.id ${ }^{2}$ - indriyana_widy@yahoo.co.id ${ }^{3}$
}

Dosen STIE-AUB Surakarta, Indonesia ${ }^{12}$

\begin{abstract}
Building a bathroom is not in accordance with the provisions which further worsens the situation. The behavior of elementary school students if going in and out of the school bathroom most do not maintain personal hygiene and bathroom. This is because there are no sink facilities, handwashing soap, wipes, and enough water. This has an impact on the health levels of students now and in the future. Education discipline and hygiene should start from childhood when going into a very special and personal place where the source of honesty and sincerity will be seen in the behavior outside the bathroom. The purpose of dedication is to make an existing bathroom, more comfortable to use. The method used is: Giving knowledge, attitude formation, and engineering skills through examples and lectures and discussions, practice and movie playback
\end{abstract}

Keywords: Discipline, Maintain public facilities, Become Exemplary, Mutual Cooperation, Protecting the environment

\section{Introduction}

Beskalan Public Elementary School is a State Primary School located next to Bromantakan State Elementary School. In terms of economy, the State Primary School in Beskalan is lower than Bromantakan State Elementary School. Has 143 students consisting of 59 men and 84 women with 11 teachers, consisting of 3 male teachers and 8 female teachers, 8 PNS teachers and 3 teachers Wiyata Bhakti. Too many problems after the government rolled out a free school program. schools cannot withdraw fees and access the ease of communicating with the mayor and government officials make the school all wrong. Having school facilities and infrastructure can use funds from the government, but for the maintenance costs, it is not enough for funds from the government. So that the Primary School through the Principal applies every day to his students with a "5-minute clean" program, taking turns from Monday to Saturday, sequentially for grades 1 through grade 6. This program is done after each break. Unfortunately, clean water is the capital for cleaning up and the bathroom is very limited.

Bromantakan State Elementary School Surakarta, Has a Mission to educate prospective future successors through basic education, Progress together in achieving achievements, increasing faith and devotion and carrying out education for all. The school's vision is to create a quality, faithful and pious young generation. Is an inclusive school that is expected to be an example in educating students to have an empathy spirit that is more able to mingle with students with special needs and is expected to be beneficial for all parties, namely on the side of normal children, they are conditioned to be able to learn to accept people's weaknesses others, learning to tolerate and learn to be patient. In Bromantakan Primary School there are 19 children with special needs (2016).

1.1 Problem Formulation

a. General Problems

1) There are students with special needs in Bromantakan Primary School, while in Primary Schools all students are normal 
2) Although in the curriculum there is a self-development of habit about clean culture but the smell of the school bathroom that smells remains.

3) The bathroom is in a humid condition

4) Bathroom management is the full responsibility of the school

b. Special Issues

1) Need for clean water

2) Clean bathrooms/toilets are suitable for use

3) Sink that has no hand washing soap

1.2 The output targets achieved in this activity are as follows:

a. Awareness of elementary school students and parents of students About the importance of cleaning the school bathroom

b. Sufficient supply of clean water

c. Improving School Bathroom Management

d. Provision of a decent school sink

e. Training and teaching of elementary students and parents/guardians of students

\subsection{Benefits}

a. General Problems

1) It is expected that students with special needs can also mingle with normal students

2) Conditioning the smell of the bathroom so as not to smell and not humid

3) Bathroom Management is the responsibility of all parties, including CSR from other companies or social institutions.

4) The health of students can be maintained and become a clean and healthy culture for people's lives.

b. Special Issues

1) Clean water needs can be overcome

2) Clean bathrooms/toilets are suitable for all parties

3) Washbasins have hand washing soap and towels

\section{Literature Review}

Elementary school students currently spend average time 8 hours a day and 3 or 4 times to the toilet, students prefer snacks outside of school that are widely available. While the hand washing place with a basin in front of the class does not help, because the water does not flow. Pediatrician Rouli Nababan said bad toilets in schools could cause children to be afflicted with various diseases. Rouli claimed to often find parents complaining of illness in children because the toilet is not clean and hygienic. Starting from diarrhea, acute respiratory infections (ARI), typhus, dysentery, to urinary tract infections.

This disease arises from germs that nest in the bathroom or dirty toilets. Rouli explained, germs can multiply once every 20 minutes. Within 24 hours it can be 8 million cells, causing a bad smell in the bathroom. Finally, children are easily infected with the disease.

Achievement at school can also decrease. "The learning process can be disrupted, they become less concentrated because they hold back the water. Often do not go to school because of illness, achievements can also decrease, "said Rouli in Jakarta, Tuesday (11/18/2014) kompas.com.[1]

The number of toilets in schools must be sufficient with age-appropriate designs. The ratio of the number of toilets and children for elementary school is 1:25 or one toilets for 25 children, then 1:50 for junior high school, and 1:75 for high school.

The toilets for boys and girls must be separated and there must be officers who clean the toilets after using more than 3 (three) people. Germs can develop very quickly if the toilet is dirty and not cleaned as it should. Because every 20 minutes, the germs easily develop.

Construction of toilets must also be considered. Indonesia is a tropical country so that the toilet can become very humid if there is no air circulation. Bacteria will easily multiply. According to UNICEF 2.5 million people have not received clean or proper toilets while a third 
of the world's people suffer from worm infections due to dirty toilet use and 1800 children die every day due to diarrhea[2].

\section{Discipline And School Bath Management}

1. Awareness of elementary school students and parents of students About the importance of cleaning the school bathroom.

Elementary students are expected to be the pioneers of hygiene discipline, especially school bathrooms. They include early age, who learn and can understand if given examples of habits and simple understanding. It is hoped that by becoming a pioneer, they can keep the school bathroom or another public bathroom even other public facilities can be maintained in a spontaneous way because it is part of the living culture. Parents can learn together and are expected to remind their sons and daughters to be disciplined in maintaining the cleanliness of the bathrooms both at home, at school and other public bathrooms.

The main targets in this activity are:

a. Obtain information about socio-economic and socio-cultural conditions, students through parents/guardians

b. Awareness of the public about the importance of bathroom cleanliness,

c. Training and teaching of elementary school students and parents/guardians regarding the use of school bathrooms is good and right.

d. Improving school bathroom management

e. Supply of clean water and school sink

f. Discipline becomes a national culture

2. Sufficient supply of clean water

Clean water is available enough so students can be freer to clean themselves. It is wiser for bathroom and sink equipment to support efficient water use and efficient and effective ways of using clean water for students.

3. Improving School Bathroom Management

Some people still see the cleanliness of the school bathroom, especially public schools. Even though every child in 1 day at least 1 time uses the school bathroom. At school, they are learning activities and interspersed with breaks to eat. Children buy food, both in the school cafeteria and outside the school fence at the traveling merchants. Even though they have brought supplies from home. Even though the school fence has been closed.

Children mostly forget to wash their hands before eating. After eating on average students wash their hands, in the bucket provided in front of the class. 1 basin of $30 \mathrm{~cm}$ in diameter is used together for 1 class / as many as 30 students, water in the basin is not replaced from the first hour to the last hour. After coming from the bathroom there was no proper sink with clean water flowing enough to make the students' hand hygiene not guaranteed.

4. Provision of proper school sinks

One important aspect of the management of school bathrooms is human resources. In this case the strengthening of human resources aspects, especially elementary students who are expected to embed the values that have been given in the form of simple training can be recorded at any time and they are expected to be ambassadors of cleanliness in their surroundings, as for the training will be carried out, as follows:

a. General and personal hygiene coaching

b. Management of Bathroom Coaching

c. Development of sink management

d. Assistance in cleaning up and cleaning the bathroom after being used with clean water to be effective and efficient.

e. Hygiene assistance using the sink (Will enter the bathroom, after leaving the bathroom and going to eat) 
5. Training and teaching of elementary school students and parents/guardians of students

The working phase can later formulate a school bathroom management model $/ \mathrm{model}$ that is feasible and potential to be developed in accordance with the characteristics of elementary school students school bathroom management structures that have high discipline quality and capability to ensure the health of the nation's children and the clean culture of school bathrooms. It is expected that school committees can arrange school bathrooms through parents/guardians. because all this time the parents' meeting every once a month the agenda only provides school information (1 direction only) there is no work program to maintain the school environment and children's health.

6. Supply of clean water and school sink

The bathroom and sink will remain clean if there is enough clean water.

For example, to urinate with 5 diapers and a good watering technique, the bathroom can remain clean and not smell/leave an odor. To defecate with 10 tablespoons measuring 1 liter of water, washing hands with liquid soap can clean the children and the toilet is clean and does not leave a smell while washing hands using running water.

\section{METHOD}

1. Is giving material theoretically

2. Training

3. Case Settlement from the Field

The training activities were conducted using survey methods, lectures, training practices, discussions, and consultations. The survey was conducted by interviewing 'user need assessment' to parents, the basis for obtaining data, the type and needs of students in using the school bathroom while students were in school.

The lecture method, training practice, and discussions were conducted during the training activities. Method did:

1. Lecture, the explanation was given to participants in terms of deeper exploration of the packaging they are now using and packaging that is good and can increase the value of their products.

2. Explanations are accompanied directly by training practices

3. During the training, participants were facilitated in conducting discussions to discuss problems that arise in school bathroom management.

a. Training place

In SD Negeri 56 Bromantakan

b. Companion

4 (four) students consist of undergraduate students in Management and Accounting.

\section{DISCUSSION}

1. Discussion

a. Understanding School Sanitation 
According to the Decree of the Minister of Health RI Nomor 852/MENKES/SK/IX/2008[3] about the National Community Based Sanitation Strategy explain total sanitation is a condition when a community does not defecate (BAB) carelessly, hand washing using soap, managing safe drinking water and food, manage garbage properly, and manage waste safely. In the opinion of WHO, sanitation is an effort to control all human physical environmental factors, can cause harmful things to physical development, health and endurance of human life.

b. Sanitation Components

Decree of the Minister of Health of the Republic of Indonesia No. 852/MENKES/SK/IX/2008[3] concerning Guidelines for Implementing School Environmental Health, School sanitation facilities consists of clean water, toilets, sewerage (SPAL), and garbage disposal facilities.

1) Clean water

Based on the Minister of Health Regulation of the Republic of Indonesia No. No. 416/Menkes/Per/IX/1990[3] regarding Water Quality Terms and Supervision, "Clean water is water that is used for everyday purposes whose quality meets health requirements and can be drunk if it has been cooked".

According to other regulations, based on the Decree of the Minister of Health of the Republic of Indonesia Number 1429 / MENKES / SK / XII / 2006[4] concerning Guidelines for Implementation of School Environmental Health, "The standard of clean water in schools is:

a) 15 liters/person/day of clean water is available.

b) Clean water quality meets the health requirements that are in accordance with health minister's decision 416 the year 1990 about water quality requirements and supervision.

c) Distance of wells / clean water facilities with sources of pollution (wastewater disposal facilities, septic tanks, final landfills, etc.) at least 10 m. "

d) Source of clean water providers:

technical health requirements from sources of clean water supply according to the Ministry of Health of the Republic of Indonesia quoted by Eka Irdianty (2011: 16-18)[5]:

(1) Dig well

(a) Location, A distance of at least 10 meters from polluted sources such as latrines, dirty water/sewage shelters, landfills, or livestock pens.

(b) Floors, The floor must be waterproof, at least 1 meter from the edge / well wall, not cracked / leaking, easy to clean and not flooded (minimum slope of $1 \%-5 \%$ )

(c) the lip of the well, The height of the surface of the well is $80 \mathrm{~cm}$ from the floor, made of strong and tight water.

(d) Well walls, The well wall is at least 3 meters deep from the floor from waterproof and strong material (not easily cracked).

(e) Close the well, If taking water with an electric pump must be closed tightly. If taking water with a bucket there must be a special bucket with a rope.

(2) Hand Pump Well

(a) Location, The distance of the hand pump well is at least 10 meters from polluted sources such as latrines, dirty / sewerage reservoirs, landfills, pens or livestock.

(b) Floors, The floor must be waterproof, at least 1 meter from the edge / well wall, not cracked / leaking, easy to clean and not stagnant (slope minimum $1 \%-5 \%$ ) 
(c) Protective pipe, The suction pipe at the top is at least 3 meters deep from the floor protected by a protective pipe (casing) and/or cast tight water (Concrete seal).

(d) Filter pipe, The bottom end of the filter pipe is given gravel as big as corn seeds (corn gravel is approximately 2.5 meters)

2) Toilet / latrine

Based on the Guidelines for Operation and Maintenance of Communal Sanitation Facilities in Bandung Regency, which was presented by the Bandung Regency Housing, Spatial and Sanitation Office on 4 July 2013, explained the operation and maintenance instructions for MCK managers are as follows:

a) every day clean the dipper with a brush or belt

b) 2 (two) times per day use a mop to clean the outside terrace (use cleaning material if it is very dirty)

c) every day clean the filter on the floor of the toilet/toilet from solid dirt

d) every day throw garbage from the bathroom/toilet

e) every day clean the floor and walls of the bathroom / WC using a brush (use cleaning material if it's very dirty)

f) every day clean the toilet using the toilet brush

g) every day drain the tub with a brush (use cleaning material if it's very dirty)

h) 1 (one) time every week drain and clean the tank/water reservoir from moss and other dirt

i) 1 (one) time each month clean the bathroom / WC ceiling from the cobwebs

j) (one) time every week check the control tub, if there is solid / garbage, remove it and then throw it into the trash

k) 1 (one) time every 6 months, remove solid waste and floating dirt right under the manhole

1) 1 (one) time every 6 months, wastewater quality test.

c. Washing hands

Hand Cleaning is an activity that physically aims to remove dirt, organic material or microorganisms (World Health Organization, 2009)[6].

Eka Irdianty (2011: 24) [5] explains that handwashing places are as follows:

1) Faucet with clean water.

2) Closed drainage channels.

3) There is a water reservoir.

4) Soap is available.

5) Wipe to dry your hands with one use.

6) A number of handwashing places according to hand washing ratio. One hand washing place for 1-10 people

7) Washing places are placed in a place that can be seen and easily accessible.

d. Hand Washing Place

According to the Technical Guidelines for Management of Madrasah Environmental Hygiene (2012: 7)[6], how to clean the sink, marble floor, glass and mirror glass are as follows:

1) Do not open and close the faucet hard.

2) Clean the filter at the sink.

3) Spray the cleaning liquid into the sink bowl evenly.

4) Rub the sink bowl with foam cleaner thoroughly until the dirt is gone.

5) Water the sink with clean water.

6) Wipe the surface of marble with warm water and prevent the cleaning material from affecting the surface of the sink.

7) Wipe the mirror frame part made of wood with supporting cleaning material. For the labeled frame, use oil. 
8) For frames with metal finishing, use a kind of brass material, or with a cloth that is not too wet.

9) Clean the mirror and ordinary glass with a glass cleaner, then wipe with a cloth or use a glass sweeper.

10) Wash hand towels every day.

11) Check damage and fix it

e. Public toilets

public facilities that are used jointly by several families to bathe, wash and defecate in residential areas with moderate to high density (300-500 people / Ha)

Public toilet wash requirements

1. General requirements for MCK

a. plans for the construction of coal-fired public toilets can be carried out after fulfilling the requirements that have been determined as follows: location, number of users, water supply system, sewerage system.

b. the ability of the MCK manager

c. water, waste from public MCK must be treated before being disposed of so as not to pollute the water, air, and soil in the neighborhood

2. Location

The maximum distance between public MCK locations and residential houses is 100 meter.

The location of the area must be free of flooding.

3. Service capacity

All rooms in one unit must be able to accommodate services at the busiest time (hours) and the number of rooms in each one MCK unit for the amount

certain users

4. The clean water supply system

a. Source of clean water

1) PDAM (Perusahaan Daerah Air Minum)

2) groundwater: a source of clean water that comes from groundwater, its location is at least 11 $\mathrm{m}$ from the source of contamination of clean water sources and groundwater extraction can be in the form of boreholes and dug well:

3) rainwater: for areas with rainfall above $1300 \mathrm{~mm} /$ year can be made either rainwater reservoir

4) springs: equipped with water catching structures.

b. Water quantity

The quantity of water adjusted for MCK units is: Minimum 20 Liters/ person/day for bathing, Minimum 15 Liters/ person/day for washing and Minimum 10 Liters/ person/day for latrines

c. Water quality

Clean water to be used must meet applicable water quality standards.

d. Bathroom facilities

The entrance to the bathroom that is not equipped with a door must be made in such a way that the person who is taking a shower is not seen directly from the outside.

e. Toilet facilities

Toilet facilities requirements are as follows:

1) Floor area of at least $2.0 \mathrm{~m} 2(1.0 \mathrm{~m} \times 2.0 \mathrm{~m})$ and made not slippery with candlenut towards the floor drain.

2) Walls, ventilation doors and, lighting when equipped with walls, doors, ventilation and lighting, the provisions such as those contained in bath facilities for walls, doors, ventilation, and lighting can be applied to latrine facilities 
3) Squat toilet with the following conditions:
a) the place of the foot must be made as squat toilet equipment
b) the diameter of stool entry hole $10 \mathrm{~cm}$
c) the distance between the walls of the building to the toilet is $20 \mathrm{~cm}-25 \mathrm{~cm}$
d) toilet length $40 \mathrm{~cm}$ and width $20 \mathrm{~cm}$
e) the toilet seat can be raised at least $10 \mathrm{~cm}$ from the floor with a slope of $1 \%$ equipped with a water trap
f) clean water facilities and the number of faucets used must be adjusted to the needs.

f. Someone must clean the toilet, but no one likes cleaning the toilet. But there must be someone who does it.

Often, the work of planning, building, and repairing toilets is considered to be the work of male groups or jobs for specialists. An unpleasant task and often falls among women or those with low social status. Of course, it is unfair if such tasks always fall on women and the poor who usually do not take decisions. Sharing unpleasant tasks is a way of ensuring that work is successfully completed, even though it often brings social conflict.

\section{g. Men and Women Have Different Needs}

Women and men have different needs and habits regarding the use of toilets. Compared to women, men may not feel awkward urinating in public or open places. Women have more household duties such as caring for children, looking for water, firewood, cooking, and cleaning. This certainly affects their access to safe, clean, comfortable and private toilets.

There are many ways to make toilets easier for children and disabled people who have limitations. People adapt differently depending on their individual abilities so that in making planning it should involve people with disabilities. Solutions can be made as creative as possible in meeting everyone's needs. If someone has difficulty squatting, make a simple handle or a higher seat. If the toilet is built on the ground, make a hole in the seat or chair and place it on the toilet. If a person has difficulty controlling his body, provide a backrest for his back, left and right body, and legs, as well as a belt or fastening board.

\section{Toilets for children}

Children are at great risk of falling ill because of poor sanitation. And while adults can survive diarrhea and intestinal worms, children can actually die from these diseases. When children have access to a toilet that is comfortable to use and has an easy way to clean it, they will rarely get sick. Lots of children, especially women, leave school because the school does not have a safe toilet.

Inviting children to help build toilets and teach them about diseases caused by poor sanitation will help them develop healthy behaviors.

Teach boys and girls how to rinse properly, and always wash their hands after using the toilet. In particular, girls must be taught to clean the vagina vertically and towards the back/anus.

a. Salt

Salt is a neutral $\mathrm{pH}$ compound consisting of $\mathrm{Na}+$ and $\mathrm{Cl}-$ atoms. Is one of the electrolyte components that are needed by humans, animals, and plants.

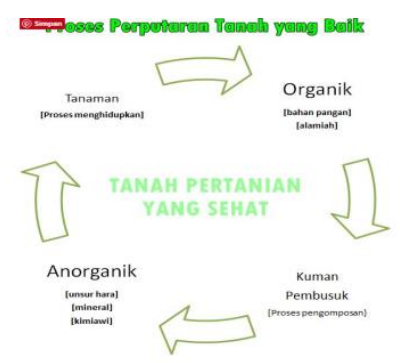




\section{Benefits of Salt}

1. The effect of salt will make the dirt break, Chlorine anion is a group of halogens found in large quantities in the body of living things. Useful as a bio-activator to catalyze germs to decompose various organic materials/complex compounds such as carbohydrates, fats, and proteins. In its utilization, the use of $\mathrm{NaCl}$ can be divided into two, namely as an ingredient to accelerate decomposition and at the same time as a preservative (holding the decay process). The use of this efficacy can be used separately. That is, in conditions of low salinity $(<3.5 \%$ oceans) it is useful to accelerate decay

2. Salt containing hydrochloric acid is also used for the process of purifying kitchen salts. For the purpose of regulating acidity or $\mathrm{pH}$, the role of hydrochloric acid is also very important, namely to regulate $\mathrm{pH}$ in wastewater. Hydrochloric acid is found in household products such as porcelain cleaners.

3. The sulfur content helps to synthesize potassium oxygenation to maintain air balance for metabolism, making it possible to collect dirt. The calcium content in salt can cleanse the pores, and make the cell membrane stronger. Magnesium content can remove dirt and toxins.

4. sea salt also contains magnesium which is useful for regulating hundreds of biochemical processes in the metabolic and cardiovascular systems.

5. Soil contains two types of germs (bacteria \& fungi) which are good bacteria that are beneficial to plants and bad bacteria that harm plants. Therefore, it takes an environmental engineering where the germs grow well while the bad germs are inhibited and eliminated (removed) from the soil environment. Salt is an essential substance needed to grow good bacteria while the bad ones are eliminated

7. Conclusion

a. Most students if they have used the bathroom are not aware of cleanliness. The hands are dried in their pants/skirts because the school is considered not to provide facilities and infrastructure/sinks near the school bathroom.

b. There are still many female students choosing not to use the bathroom even though it is an urgent need.

c. The absence of adequate facilities and infrastructure makes a culture of healthy living and self-discipline of cleanliness unable to form.

d. Bathroom treatment is still a burden for schools.

e. Meeting parents have never discussed the cleanliness of the school bathroom

f. There are still many community members who are not aware of self-respect through cleanliness

g. There are still many members of the community who are not yet aware of maintaining health for their present and future lives (Long Term)

h. Indonesia is a country where most of its territory is sea, produce lots of salt, produce lots of salt, salts contain compounds with neutral $\mathrm{pH}$ consisting of $\mathrm{Na}+$ and $\mathrm{Cl}$ - atoms. Is one of the electrolyte components that are needed by humans, animals, and plants. Cleaning the bathroom should use salt. Because it is environmentally friendly.

i. Good knowledge and maintaining the cleanliness of the bathroom together will foster the nature of mutual cooperation, empathy, discipline and care for the environment in the nation that starts small. They will get good health and

\section{Suggestion}

Synergy between the government (schools), stakeholders (companies), universities and the community to be able to jointly empower themselves and cultivate themselves through personal hygiene discipline in the bathroom, both at home, school and public place, can help to shape Indonesia's human character that is disciplined, mutual cooperation, has empathy and cares for the environment. 


\section{References}

[1]

(2003). Keputusan Menteri Kesehatan Nomor 1098/MENKES/SK/VII/2003: Tentang Persyaratan Hygiene Sanitasi Rumah Makan dan Restoran. Jakarta: Departemen Kesehatan

[2] _. (2006). Keputusan Menteri Kesehatan RI No 1429/MENKES/SK/XII/2006: Tentang Pedoman Penyelenggaraan Kesehatan Lingkungan Sekolah. Jakarta: Departemen Kesehatann 2014 darihttp: www.who.int/gpsc/5may/How_To_HandWash_Poster.pdf .

[3] Dikpora.Surakarta.Go.Id

[4] Eka Irdianty. (2011). Studi Deskriptif Sanitasi Dasar di Tempat Pelelangan Ikan Lempasing Teluk Betung Bandar Lampung. Skripsi. Universitas Indonesia.

[5] Http://Google.Co.Id/Search?Q=Kebersihan+Kamar+Mandi+Sekolah+Tingkat+SD\&Biw

[6] http://hesperian.org/wp-content/uploads/pdf/id_cgeh_2010/id_cgeh_2010_07.pdf

[7]Http://Www.Sdsantoyoseph1denpasar.Sch.Id/Html/Guru.Php?Id=Profil\&Kode=66\&Profil= Kamar\%20Mandi\%20dan\%20WC

[8] Ineke Feryasari, Pemeliharaan Sanitasi Di Sekolah DasarNegeri Se-Kecamatan Jetis Kabupaten Bantul, Universitas Negeri Yogyakarta Juli 2015

[9] Kementerian Kesehatan RI. (2002). Keputusan Menteri Kesehatan No 965/Menkes/SK/VII/2002 tentang Syarat-Syarat dan Pengawasan Kualitas Air Minum. Jakarta: Departemen Kesehatan

[10] KOMPAS.Com.Selasa (18/11/2014)

[11] Nani Dan Anwar, 2015 "Pemanfaatan Sarana Toilet Umum Dan Kesehatan Wanita" STIEAUB Surakarta

[12] Profil Sekolah SDN Bromantakan 56 Surakarta

[13] UNICEF INDONESIA, Ringkasan Kajian OKTOBER 2012

[14] Unicef Indonesia. (2012). Ringkasan Kajian Air Bersih, Sanitasi \& Kebersihan. Diakses tanggal 23 Juni 2015 dari http://www.unicef.org/indonesia/id/A8__B_Ringkasan_Kajian_Air_Bersih.pdf

[15] World Health Organization. (2009). How to Handwash? Wash Hands When Visibly Soiled! Otherwise, Use drub. Diakses tanggal 26 November

[16] World Health Organization. (2010). Guide to Implementation of the WHO Multimodal Hand Hygiene Improvement Stategy. Diakses tanggal 27 November 2014 dari http://etd.eprints.uns.ac.id/

[17] https://lasealwin.com/2016/10/14/manfaat-garam-sebagai-pupuk-organik-terbaik-untukmenyuburkan-tanah/

[18] http://www.martinrecords.com/info/penjelasan-mengenai-garam-serta-manfaatnya-yangmungkin-belum-kamu-ketahui/

[19] http://www.martinrecords.com/info/penjelasan-mengenai-garam-serta-manfaatnya-yangmungkin-belum-kamu-ketahui/

[20] https://www.republika.co.id/berita/gaya-hidup/tips/16/10/05/oejvgc328-10-manfaat-garamyang-belum-pernah-diketahui 